\title{
The National Institute of Public Health: Shaping Public Policy to Advance Population Health in Mexico
}

\author{
Laura Magaña-Valladares, $\mathrm{PhD},{ }^{1}$ \\ Kelly Cooper, $\mathrm{MA}^{1}$
}

\begin{abstract}
The Mexican School of Public Health was founded in 1922 by the Mexican government and was the first school of public health in Latin America. It has become one of the largest public health institutions in the developing world and is the leading institution for teaching, research and service to improve public health in Mexico and Latin America. The Institute is an important player in shaping public policy in Mexico through its mission-oriented research. Through its research initiatives, the Institute has influenced policies regarding tobacco, obesity, milk and flour fortification, malaria, cancer, environmental health, and other public health priority areas. The Institute responds to changing health workforce training needs. It currently offers 28 competency-based graduate degree programs and trains annually more than 10,000 in-service public health workers through continuing education courses. The Institute offers multiple educational formats to accomplish its mission, including face-to-face, virtual, and blended learning. It has been accredited by both national and international agencies and collaborates closely with international institutions. The Institute contributes to global health by promoting health equity, strengthening health systems, and generating evidence-based strategies to improve population health in Mexico, the Americas, and around the world.
\end{abstract}

Key Words: Public health, Mexico, Ministry of Health of Mexico

Recommended Citation: Magaña-Valladares L, Cooper K. The National Institute of Public Health: Shaping Public Policy to Advance Population Health in Mexico. Public Health Reviews. 2011;33:331-8.

\footnotetext{
${ }^{1}$ Instituto Nacional de Salud Pública.

Corresponding Author Contact Information: Laura Magana-Valladares at lmagana@insp. mx; Instituto Nacional de Salud Pública. Avenida Universidad No. 655, Colonia Santa María Ahuacatitlan, C. P. 62100 Cuernavaca, Morelos, México.
} 
The Mexican School of Public Health was founded in 1922 by the Mexican government in response to the recommendations of the Welch-Rose report (published in the United States in 1918). It was the first school of public health in Latin America and the second in the Americas, after the School of Hygiene and Public Health at Johns Hopkins University. ${ }^{1}$ In 1987, the School of Public Health merged with the Population Health Research Center and the Infectious Disease Research Center to create the Instituto Nacional de Salud Pública (INSP), or National Institute of Public Health, with the goal of consolidating research, graduate training and continuing education to strengthen health systems and respond to public health challenges. ${ }^{2-5}$

The INSP has become one of the largest public health institutions in the developing world and has gained international recognition as a state of the art institution for research, training, and service. In particular, the INSP is well recognized for its ability to influence public policies through its mission-oriented research. The INSP's research mission is to improve the health of the population through the production, dissemination, and implementation of scientific knowledge about health conditions and organized social responses, based on disciplines and methods in public health.

The INSP works closely with the Federal Ministry of Health to contribute to strengthening health systems by conducting national health surveys, providing support for epidemiological monitoring of infectious diseases and other health problems, developing diagnostic technologies for transmissible diseases, and evaluating and/or performing diagnostic services for community sectors that require these services. The INSP's strategic objectives are established in accordance with the National Development Program, as presented in the National Health Program 20072012. In the last four years (2007-2010), the INSP has supported the development of more than 500 research and service projects and 290 projects are currently underway. ${ }^{6}$

INSP research has been instrumental for the development of public policies in Mexico, as national health surveys and evaluations of health programs and interventions provide information for decision-making in the implementation and development of social programs. For example, in 1999, the National Nutrition Survey found a large proportion of children with iron deficiency anemia. ${ }^{7}$ The results were presented to the Ministry of Health and the Ministry of Social Development and recommendations were made to implement or modify existing programs to improve the iron status of Mexican children. A federal program that distributed subsidized milk at 
low cost to low income households was used as a vehicle for improving iron status. The milk was fortified with iron and other micronutrients and rigorous impact evaluations have demonstrated an effect of the new program in the reduction of anemia. ${ }^{8}$ The INSP has carried out similar projects regarding fortified flour, which have resulted in the improvement of population nutrition. ${ }^{9}$

Another example of the INSP's impact on public policy in Mexico is the case of tobacco control. The INSP developed research to evaluate the impact of public policies against tobacco use on adult Mexican smokers. ${ }^{10-12}$ The objective of this initiative was to evaluate the psychosocial and behavioral impact that public policies promoted by the World Health Organization Framework Convention on Tobacco Control, including increased taxes on tobacco sales, packaging regulations to increase the size and format of warnings on cigarette packs, and prohibiting smoking in public areas and work places, ${ }^{13,14}$ have had on Mexican smokers. As a result, the recently approved Mexican legislation in regard to tobacco control, called the General Tobacco Control Law and the Protection Act for NonSmokers in Mexico City, has largely been influenced by INSP research and advocacy ${ }^{15}$

The INSP is an important adviser in Mexico on public policies for the prevention and control of cancer in women. As a result of population-based studies about cervical cancer screening programs, HPV testing has been incorporated at the federal level with a particular focus on the poorest areas of the country. ${ }^{16}$ This has led to more efficient detection of precursors to cancer lesions in women at high risk. ${ }^{17}$ In the past 15 years, evidence generated by the INSP has led to increases in screening coverage, improvements in quality assurance in diagnosis and treatment, and substantial reductions in cervical cancer mortality rates. ${ }^{18}$

The INSP has evaluated the processes involved in the Mexican Institute for Social Security Oportunidades Program, which provides health care services across the country. ${ }^{19}$ The objectives of the study were to review program norms and operation, monitor the achievement of strategic targets, identify opportunities for improvement, and evaluate the perception that the users have of the health services offered. The evaluation found fragmentation and heterogeneity in the provision of health services and a need to improve documentation..$^{20}$ This study and more recent surveys have helped the program to improve health care for its beneficiaries, which has been particularly important for health promotion and prevention in lowincome communities. ${ }^{21}$ 
The INSP has played a significant role in raising awareness about Mexico's obesity epidemic, which affects all ages and social groups. ${ }^{22}$ The Institute has conducted epidemiological studies about the magnitude, distribution and trends of obesity as well as trials in schools and other settings aimed at preventing or controlling obesity. ${ }^{23,24}$ Using this research, the INSP advised the Ministry of Health in the development of a national agreement for the prevention of obesity, which was announced by the President in 2010.

As part of the ESMaestras disease prevention project, free clinical studies, prevention talks about chronic diseases common in women, a health newsletter, and tips for health lifestyles are offered to 100,000 women teachers in rural, urban and indigenous communities across Mexico. This program offers medical follow up for 20 years to prevent and provide an early detection of frequent diseases like breast and cervical cancer and diabetes, among others. This project was made possible through a formal agreement with the National Union of Education workers, one of the biggest organizations in the country.

Additionally, the INSP offers technical consulting for community groups that seek services, such as presentations and strategic preventive actions, on specific public health topics. For example, the INSP Infestation Control Unit provides consulting for states and municipalities on activities to prevent and control dengue fever, malaria and other vector-borne diseases. It also conducts support activities in response to specific environmental conditions, such as the floods in northern Chiapas in 2007 and Tabasco during 2008. The unit provides training and monitoring for chemical control of disease vectors (e.g., dengue fever, malaria, Chagas, etc.) and organizes community talks and social promotion efforts to achieve greater collaboration with the community. ${ }^{5,6}$

In order to train the workforce to carry out public health leadership, advocacy and advance population health, the INSP offers a wide variety of training programs. The Institute has always responded to national and regional public health training needs by designing innovative graduate degree programs as well as continuing education programs. In the first half of the twentieth century, the Master of Public Health program was created, as Mexico needed public health practitioners to address diverse challenges. Later, the INSP developed research-focused programs to address the need to train public health researchers. The INSP currently offers 28 professional and research-focused degree programs, including the Master of Public Health with ten concentration areas, Masters of Health Sciences with 11 areas of concentration, Doctorate in Public Health, Doctorate in Public 
Health Sciences, Specialty in Health Promotion, and Residency in Public Health and Preventive Medicine. The Institute has a total population of 750 active students and more than 240 full-time professors.

The INSP has developed multiple educational formats to accommodate the personal and professional demands of health workers who seek training. Full-time programs are offered at the Cuernavaca campus and executive programs are offered at the Mexico City campus. Infectious disease training programs are offered at the campus in Tapachula, Chiapas. The INSP also offers the Master of Public Health in an online format for working professionals who are unable to participate in classroom-based activities due to time constraints and/or location. To prepare its students to meet challenges in the field, the Institute offers a unique practicum experience through which Master of Public Health students are able to develop public health competencies by working directly with communities across Mexico.

In the past ten years, the INSP has awarded almost 1,000 graduate degrees to health professionals. INSP alumni work in a variety of public health institutions, including universities, Ministries of Health at the state and federal levels, and non-governmental organizations. ${ }^{25}$

Additionally, the Institute contributes to developing the workforce's competencies by offering a wide range of continuing education courses, many of which are implemented in partnership with the Ministry of Health and state-level health departments. These courses target different groups of health workers, from operational personnel to senior directors. The continuing education program includes classroom-based programs at INSP campuses or other sites throughout Mexico and online and blended formats for working health professionals located across the country. Using these educational formats, the Institute has strengthened the public health workforce by training over 62,000 in-service professionals over the past ten years.

The INSP recently launched its Virtual Campus 2.0 (http://www. inspvirtual.mx/), which is a virtual space where public health students, researchers, and other interested parties can collaboratively create, share, and transform public health knowledge.

The INSP received accreditation with the National Council on Science and Technology (CONACYT) in 1994 and submits all new academic programs to this council for official approval. The INSP received accreditation with the Council for Education in Public Health (CEPH) in 2006 - making it the only institution to be accredited by this body outside the US-and tropEd, a network of higher education institutions in international health, in 2008. 
The INSP constantly works to enhance academic opportunities and strengthen its role in Mexico, especially in regard to health services and policy advocacy, in order to improve population health and social equity. In order to increase the international scope of its teaching, research and service activities, the INSP collaborates with diverse institutions and organizations. It is an active member of the Association of Schools of Public Health (US) and became a member of the Association of Schools of Public Health of the European Region (ASPHER) in 2010. The INSP has collaborated with many partners in the Americas on capacity building projects, including the Pan American Health Organization, the School of Public Health of Cuba, the University of Chile, and the Ministry of Public Health and Social Welfare of Paraguay. In order to facilitate student and professor exchange, the INSP collaborates closely with institutions around the world. Additionally, the INSP has played an important role in the Mesoamerican Institute of Public Health, which is a regional initiative to strengthen national health systems and improve access to health services through technical training, monitoring and evaluation, and improved governance practices.

As it continues to grow, the INSP plans to focus on global health across its training, research and services activities. Priority areas will include chronic degenerative diseases, nutrition, health systems strengthening, reproductive health, and vector-borne diseases, among others. The Institute

seeks to contribute to global health by promoting health equity, improving health systems, training the public health workforce, and improving population health in Mexico and around the world.

Acronyms list:

INSP = Instituto Nacional de Salud Pública

Conflicts of Interest: None declared.

\section{REFERENCES}

1. Valdespino JL. Crónica de la Escuela de Salud Pública de México de 1922 a 2001: relación de sus protagonistas. Cuernavaca: Instituto Nacional de Salud Pública; 2002.

2. Instituto Nacional de Salud Pública. Quince años por acciones por la salud. Cuernavaca: Instituto Nacional de Salud Pública; 2002. p.107.

3. Instituto Nacional de Salud Pública. Instituto Nacional de Salud Pública: cinco años de vida 1987-1991. Cuernavaca: Instituto Nacional de Salud Pública; 1992. p.215. 
4. Instituto Nacional de Salud Pública. Instituto Nacional de Salud Pública: 19951996. Cuernavaca: Instituto Nacional de Salud Pública; 1995. p.43.

5. Sepúlveda AJ. Devenir de la salud pública de México durante el siglo XX. Cuernavaca: Instituto Nacional de Salud Pública; 2000.

6. Rodríguez MH. Informe de Autoevaluación 1 de enero al 30 de junio de 2010, Sesión Ordinaria 02/2010 H. Junta de Gobierno. Cuernavaca: Instituto Nacional de Salud Pública; 2010. Available from URL: http://www.insp.mx/ images/stories/Planeacion/Docs/Inf_Institucional/JUGOOct2010.pdf (Accessed 3 February, 2011).

7. Martínez SH, Casanueva E, Rivera DJ, Viteri FE, Bourges RH. La deficiencia de hierro y la anemia en niños mexicanos. acciones para prevenirlas y corregirlas. Bol Med Hosp Infant Mex. 2008;65:86-99.

8. Villalpando S, Shamah LT, Mundo V, Rivera DJ. La fortificación de la leche Liconsa con micronutrimentos: un ejemplo del uso de la investigación para la toma de decisiones en políticas sociales. In: González CT, Rivera DJ, López AG, Rubio SG, editors. Nutrición y pobreza: política pública basada en evidencia. México: Banco Mundial : SEDESOL; 2008. p.96-108.

9. Rosado JL, Camacho SR, Bourges H. Adición de vitaminas y minerales a harinas de maíz y de trigo en México. Salud Pub Mex. 1999;41:130-7.

10. Reynales SL, Rodríguez BR, Jiménez JA, Juárez MS, Castro RA. Costos de la atención médica atribuibles al consumo de tabaco en el Instituto México de Seguro Social. Salud Publica Mex. 2006;48:S48-64.

11. Jiménez RJ, Sáenz MB, Reynales SL, Waters HR, Hernández AM. The impact of taxation on tobacco consumption in Mexico. Tob Control. 2008;2:105-10.

12. Instituto Nacional de Salud Pública. Cómo promover lugares de trabajo libres de humo de tabaco. Cuernavaca: Instituto Nacional de Salud Pública; 2007. p.88.

13. Rodríguez BR, Reynales Ssu LM, Ibañez HN, Santos LR, Valdés SR, Ávila TE, Stillman F. Estrategia de vigilancia para el control del tabaco en México: Publicidad, promoción y patrocinio, empaque y etiquetado. Salud Publica Mex. 2010;52:S254-66.

14. Thrasher JF, Allen B, Reynales SL, Anaya R, Lazcano PE, Hernández AM. Análisis del impacto en fumadores mexicanos de los avisos gráficos en las cajetillas de cigarros. Salud Publica Mex. 2006;48:S65-74.

15. Guillermo TX. Espacios 100\% libres de humo: una realidad en el Distrito Federal. Salud Publica Mex. 2008;50:384-90.

16. Flores YN, Bishai DM, Shah KV, Lazcano PE, Lörincz A, Hernández M, Ferris D, Salmerón J. Risk factors for cervical cancer among HPV positive women in Mexico. Salud Publica Mex. 2008;50:49-58.

17. Gutiérrez XL, Plett TT, Madrid GC, Madrid MV. Molecular diagnosis of human papillomavirus in the development of cervical cancer. Salud Publica Mex. 2009;51:S479-88. 
18. Olsson SE, Kjaer SK, Sigurdsson K, Iversen OE, Hernandez AM, Wheeler CM et al. Evaluation of quadrivalent HPV 6/11/16/18 vaccine efficacy against cervical and anogenital disease in subjects with serological evidence of prior vaccine type HPV infection. Hum Vaccin. 2009;5:696-704.

19. Hernández AM, Hernández PB, Urquieta SJ, editors. Evaluación externa de impacto del Programa Oportunidades 2006. Tomo I: Salud y educación. Cuernavaca: Instituto Nacional de Salud Pública; 2006. p.152.

20. Zarco A, Mora G, Pelcastre B, Flores M, Bronfman M. Aceptabilidad de los suplementos alimenticios del programa Oportunidades. Salud Publica Mex. 2006;48:325-31.

21. Neufeld LM, García GA, Leroy J, Flores LM, Fernández FA, Rivera DJ. Impacto del Programa Oportunidades en nutrición y alimentación en zonas urbanas de México. In: Hernández AM, Hernández PB, editors. Evaluación externa de impacto del Programa Oportunidades 2006: Tomo II: Alimentación. Cuernavaca: Instituto Nacional de Salud Pública, México; 2006. p. 1362006.

22. Barquera S, Campos NI, Hernández BL, Flores M, Durazo AR, Kanter R, et al. Obesity and central adiposity in Mexican adults: results from the Mexican National Health and Nutrition Survey 2006. Salud Publica Mex. 2009; 51:S595-603.

23. Flores AM, Rivera PM, Jiménez CA, Barquera CS. Sobrepeso y obesidad en adultos y adolescentes en los estados fronterizos del norte de México. In: Rangel GG, Hernández AM, editores. Condiciones de salud en la frontera norte de México. Mexico: Secretaría de Salud: Comisión de Salud Fronteriza México-Estados Unidos. Instituto Nacional de Salud Pública: El Colegio de la Frontera Norte; 2009. p.299-312.

24. Caballero C, Hernández B, Moreno H, Hernández GC, Campero L, Cruz A, Lazcano PE. Obesidad, actividad e inactividad física en adolescentes de Morelos, México: un estudio longitudinal. Arch Latinoam Nutr. 2008;57:1017.

25. Instituto Nacional de Salud Pública. Memoria 2009. Cuernavaca: Instituto Nacional de Salud Pública; 2010. p.223. 